\title{
DEMPSTER SHAFER'S ROLE IN THE EXPERT SYSTEM IN DIAGNOSING PET SKIN DISEASES
}

\author{
Gita Malinda', Andi Farmadi2, Muliadi ${ }^{2}$ \\ 1,2,3 Prog. Studi Ilmu Komputer Fakultas MIPA Universitas Lambung Mangkurat \\ Jl. A. Yani Km 36 Banjarbaru, Kalimantan selatan \\ *Email: muliadi@ulm.ac.id
}

\begin{abstract}
Cats are pets that are very close to humans. Infectious pet diseases can sometimes spread quickly and can be fatal, both in animals and humans. For early prevention, the pet disease must be immediately known which in this case is a cat skin disease. To find out the diagnosis of cat skin disease using the Dempster-Shafer method. So that the results obtained the strongest confidence value of cat skin disease $\{A 1, A 3, A 4\}$ which is equal to 0.48 , which was obtained from three existing symptoms, namely wet dry crust, moist inner moist ear and frequent scratching.
\end{abstract}

Keywords: Cats, Expert System, Dempster Shafer.

\begin{abstract}
Abstrak
Kucing merupakan hewan peliharaan yang sangat dekat dengan manusia.. Penyakit hewan peliharaan yang menular terkadang dapat menyebar secara cepat dan dapat berakibat fatal, baik pada hewan dan manusia. Untuk pencegahan dini maka penyakit hewan peliharaan tersebut harus segera diketahui yang dalam kasus ini adalah penyakit kulit kucing. Untuk mengetahui diagnose penyakit kulit kucing tersebut menggunakan metode dempstershafer. Sehingga memproleh hasil Nilai keyakinan paling kuat terhadap penyakit kulit kucing $\{A 1, A 3, A 4\}$ yaitu sebesar 0,48 , yang didapat dari tiga gejala yang ada yaitu kerak kering basah, bagian dalam telinga basah lembab dan sering menggaruk.
\end{abstract}

Kata kunci: Kucing, Sistem Pakar, Dempster Shafer.

\section{PENDAHULUAN}

Kucing merupakan salah satu hewan peliharaan terpopuler di dunia. Kucing adalah binatang yang pintar, menggemaskan, menghibur dan menjadi teman dekat bagi manusia[1]. Penyakit hewan yang bersifat menular terkadang dapat menyebar secara cepat dan dapat berakibat fatal, baik pada hewan dan manusia, untuk memelihara hewan peliharan diperlukan pengetahuan baik terutama dalam hal perawatan. Hewan peliharan jika sudah terinveksi virus atau sakit terkedang manusia tidak dapat mengidentifikasi penyakit yang sedang dialami hewan peliharaannya terutama dalam hal mendiagonsa penyakit kulit kucing, untuk itu perlu dilakukann anaisis dengan metode dempster-shafer yang selanjutnya diterapkan pada system pakar untuk diagonosa penyakit kulit kucing.

Proses pelacakan kesimpulan untuk memperoleh suatu keputusan juga terkadang sering mengalami beberapa faktor penghambat. Hal ini disebabkan karena adanya perubahan terhadap pengetahuan yang menyebabkan proses penentuan kesimpulan juga mengalami perubahan. Peristiwa ini dalam sistem 
pakar disebut sebagai faktor ketidakpastian [7]. Metode Dempster-Shafer merupakan metode penalaran non monotonis yang digunakan untuk mencari ketidakkonsistenan akibat adanya penambahan maupun pengurangan fakta baru yang akan merubah aturan yang ada, sehingga dipilihlah metode Dempster-Shafer karena dapat memungkinkan seseorang aman dalam melakukan pekerjaan seorang pakar, sekaligus dapat mengetahui probabilitas atau prosentase dari penyakit yang mungkin diderita. Pemanfaatan sistem pakar ini untuk mendiagnosa penyakit kulit kucing dengan teorema Dempster-Shafer untuk mencari besarnya nilai kepercayaan gejala dan faktor resiko tersebut terhadap tingkat kemungkinan kucing terkena penyakit kulit [6].

\section{METODE PENELITIAN}

Untuk perhitungan menggunakan metode Dempster Shafer, ada beberapa langkah yang harus dilakukan, yaitu :

a. Menentukan Nilai Belief (Bel)

Untuk nilai belief yang di dapat dari hasil wawancara kepada pakar yaitu dokter hewan dengan tabel penentuan kepastian gejala terhadap penyakit yang dapat dilihat pada tabel 1 yang ditentukan oleh peneliti dengan mengacu beberapa sumber untuk memudahkan pakar dalam menentukan persentase nilai keyakinan suatu gejala terhadap suatu penyakit.

Tabel 1 Penentuan Persentase Nilai Belief Gejala

\begin{tabular}{lc}
\hline \multicolumn{1}{c}{ Uncertain Term } & Certainty \\
\hline Definitely not (pasti tidak) & 0 \\
Unknow (tidak tahu) & 0.2 \\
Maybe (mungkin) & 0.4 \\
Probably (kemungkinan besar) & 0.6 \\
Almost certainly (hampir pasti) & 0.8 \\
Definitely (pasti) & 1 \\
\hline
\end{tabular}

b. $\quad$ Menghitung Nilai Plausability (Pls)

Plausibility (Pls) akan mengurangi tingkat kepastian dari evidence. Plausibility bernilai 0 sampai 1 . Rumus Plausibility: $\mathbf{P I}(\mathbf{s})=\mathbf{1}-\operatorname{Bel}(-\mathbf{s})$.

Jika yakin akan $(-\mathrm{s})$, maka dapat dikatakan bahwa $\operatorname{Bel}(-\mathrm{s})=1$, sehingga rumus di atas nilai dari Pls(-s) $=0$.

c. Mencari Nilai Mass Function (m)

Setelah mendapatkan frame of discrement, selanjutnya adalah mencari nilai Mass function (m). Tetapi, sebelum mencari nilai dari mass function (m), dalam teori Dempster-Shafer dikenal adanya frame of discernment yang dinotasikan dengan $\theta$ (theta). Frame ini merupakan semesta pembicaraan dari sekumpulan hipotesis. Misal $\theta=\{\mathrm{A}, \mathrm{F}, \mathrm{D}, \mathrm{B}\}$ dengan $\mathrm{A}=$ Alergi, $\mathrm{F}=\mathrm{Flu}, \mathrm{D}=$ Demam, B = Bronkitis.

Mass function (m) dalam teori Dempster-shafer adalah tingkat kepercayaan dari suatu evidence (gejala), sering disebut dengan evidence measure sehingga dinotasikan dengan (m). Tujuannya adalah mengaitkan ukuran kepercayaan 
elemen-elemen $\theta$. Tidak semua evidence secara langsung mendukung tiap-tiap elemen. Untuk itu perlu adanya probabilitas fungsi densitas (m). Nilai m tidak hanya mendefinisikan elemen-elemen $\theta$ saja, namun juga semua subsetnya. Sehingga jika $\theta$ berisi $n$ elemen, maka subset $\theta$ adalah $2 n$. Jumlah semua $m$ dalam subset $\theta$ sama dengan 1 . Misal $\theta=\{S, R, E, A, J\}$, dengan $S=$ Scabies, $R=$ Ringworm, $\mathrm{E}=$ Earmites dan A =Alergi Dermatitis, J = Jamur Cryptococcus. Andaikan tidak ada informasi apapun untuk memilih keempat hipotesis tersebut, maka nilai dari : $\operatorname{m}\{\theta\}=1,0$.

Andaikan diketahui $X$ adalah sub-set dari $\theta$ dengan $m_{1}$ sebagai fungsi densitasnya, dan $Y$ juga merupakan sub-set dari $\theta$ dengan $\mathrm{m}_{2}$ sebagai fungsi densitasnya, maka dapat dibentuk suatu fungsi kombinasi $m_{1}$ dan $m_{2}$ sebagai $m_{3}$. Fungsi kombinasi $\mathrm{m} 1$ dan $\mathrm{m} 2$ sebagai $\mathrm{m} 3$ dibentuk dengan persamaan dibawah ini.

$$
m_{3}(z)=\frac{\sum_{x \cap y=z} m_{1}(X) \cdot m_{2}(Y)}{1-\sum_{x \cap y=\phi} m_{1}(X) \cdot m_{2}(Y)}
$$

Seekor kucing mengalami gejala kerak warna putih di pinggiran telinga. Dari diagnose dokter kemungkinan kucing tersebut menderita Scabies, Ringworm, Earmites, dan Alergi Dermatitis. maka :

1) Gejala 1: kerak warna putih di pinggiran telinga

Apabila diketahui nilai kepercayaan setelah dilakukan observasi kerak warna putih di pinggiran telinga sebagai gejala Scabies, Ringworm, Earmites, dan Alergi Dermatitis adalah :

$$
\begin{aligned}
& \mathrm{m}_{1}\{\mathrm{~S}, \mathrm{R}, \mathrm{E}, \mathrm{A}\}=0,8 \\
& \mathrm{~m}_{1}\{\theta\}=1-0,8=0,2 .
\end{aligned}
$$

gejala pilek berat.

Sehari kemudian kucing tersebut dibawa ke dokter lagi dengan

2) Gejala 2: pilek berat

Setelah observasi diketahui bahwa nilai kepercayaan pilek berat sebagai gejala Earmites dan Jamur Cryptococcus, maka :

$$
\begin{aligned}
& \mathrm{m}_{2}\{\mathrm{E}, J\}=0,4 \\
& \mathrm{~m}_{2}\{\theta\}=1-0,4=0,6
\end{aligned}
$$

Munculnya gejala baru maka harus dihitung densitas baru untuk beberapa kombinasi $\left(\mathrm{m}_{3}\right)$. Untuk memudahkan perhitungan maka himpunan-himpunan bagian dibawa ke bentuk tabel 2 .

Tabel 2 Contoh Perhitungan Densitas

\begin{tabular}{llllll}
\hline & & $\mathrm{m}_{2}\{\mathrm{E}, J\}$ & 0,4 & $\mathrm{~m}_{2}\{\emptyset\}$ & 0,6 \\
\hline $\mathrm{m}_{1}\{\mathrm{~S}, \mathrm{R}, \mathrm{E}, \mathrm{A}\}$ & 0,8 & $\{\mathrm{E}\}$ & 0,32 & $\{\mathrm{~S}, \mathrm{R}, \mathrm{E}, \mathrm{A}\}$ & 0,48 \\
$\mathrm{~m}_{1}\{\varnothing\}$ & 0,2 & $\{\mathrm{E}, J\}$ & 0,08 & $\{\emptyset\}$ & 0,12 \\
& & & & & \\
\hline
\end{tabular}




\section{Keterangan :}

a) Kolom pertama berisikan semua himpunan bagian pada gejala pertama (kerak warna putih di pinggiran telinga) dengan $\mathrm{m}_{1}$ sebagai fungsi densitas.

b) Baris pertama berisikan semua himpunan bagian pada gejala kedua (pilek berat) dengan $\mathrm{m} 2$ sebagai fungsi densitas.

c) Baris kedua dan ketiga pada kolom kedua merupakan irisan dari kedua himpunan.

d. Menghitung Kombinasi Tingkat Keyakinan

Selanjutnya dihitung densitas baru untuk beberapa kombinasi $\left(\mathrm{m}_{3}\right)$ dengan persamaan Dempster-Shafer sbb :

$\mathrm{m}_{3}\{\mathrm{E}\} \quad=0.32 /(1-0)=0,32$

$\mathrm{m}_{3}\{\mathrm{E}, \mathrm{J}\} \quad=0,08 /(1-0)=0,08$

$\mathrm{m}_{3}\{\mathrm{~S}, \mathrm{R}, \mathrm{E}, \mathrm{A}\}=0,48 /(1-0)=0,48$

$\mathrm{m}_{3}\{\emptyset\} \quad=0,12 /(1-0)=0,12$

\section{Keterangan :}

Terlihat bahwa pada mulanya dengan hanya gejala kerak warna putih di pinggiran telinga, $\mathrm{m} 1\{\mathrm{~S}, \mathrm{R}, \mathrm{E}, \mathrm{A}\}=0,8$. Namun setelah ada gejala baru (pilek berat), maka nilai $\mathrm{m} 3\{\mathrm{~S}, \mathrm{R}, \mathrm{E}, \mathrm{A}\}=0,48$.

Demikian pula pada mulanya hanya dengan gejala pilek berat, $\mathrm{m} 2\{\mathrm{E}, \mathrm{J}\}=$ 0,4 . Namun setelah ada gejala baru (kerak warna putih di pinggiran telinga) maka $m 3\{\mathrm{E}, \mathrm{J}\}=0,08$.

Dengan adanya 2 gejala tersebut, maka nilai densitas yang paling kuat adalah $m 3\{\mathrm{~S}, \mathrm{R}, \mathrm{E}, \mathrm{A}\}=0,48$. Jadi dengan dua jenis gejala yang dialami oleh kucing tersebut, kemungkinan paling kuat kucing tersebut terkena Scabies, Ringworm, Earmites dan Alergi Dermatitis.

\section{HASIL DAN PEMBAHASAN}

Pembahasan diperlukan untuk mengetahui apakah hasil dari penelitian sudah dapat menyelesaikan permasalahan atau belum. Permasalahan yang telah dirumuskan sebelumnya adalah bagaimana merancang dan membangun aplikasi sistem pakar untuk diagnosa awal penyakit kulit pada kucing dan bagaimana menerapkan metode Dempster Shafer pada aplikasi yang dibuat untuk studi kasus yang dilakukan pada Balai Penyidikan dan Pengujian Veteriner (BPPV) Regional V Banjarbaru.

Kasus yang telah diuji melalui sistem dapat dilihat pada gambar 5. 


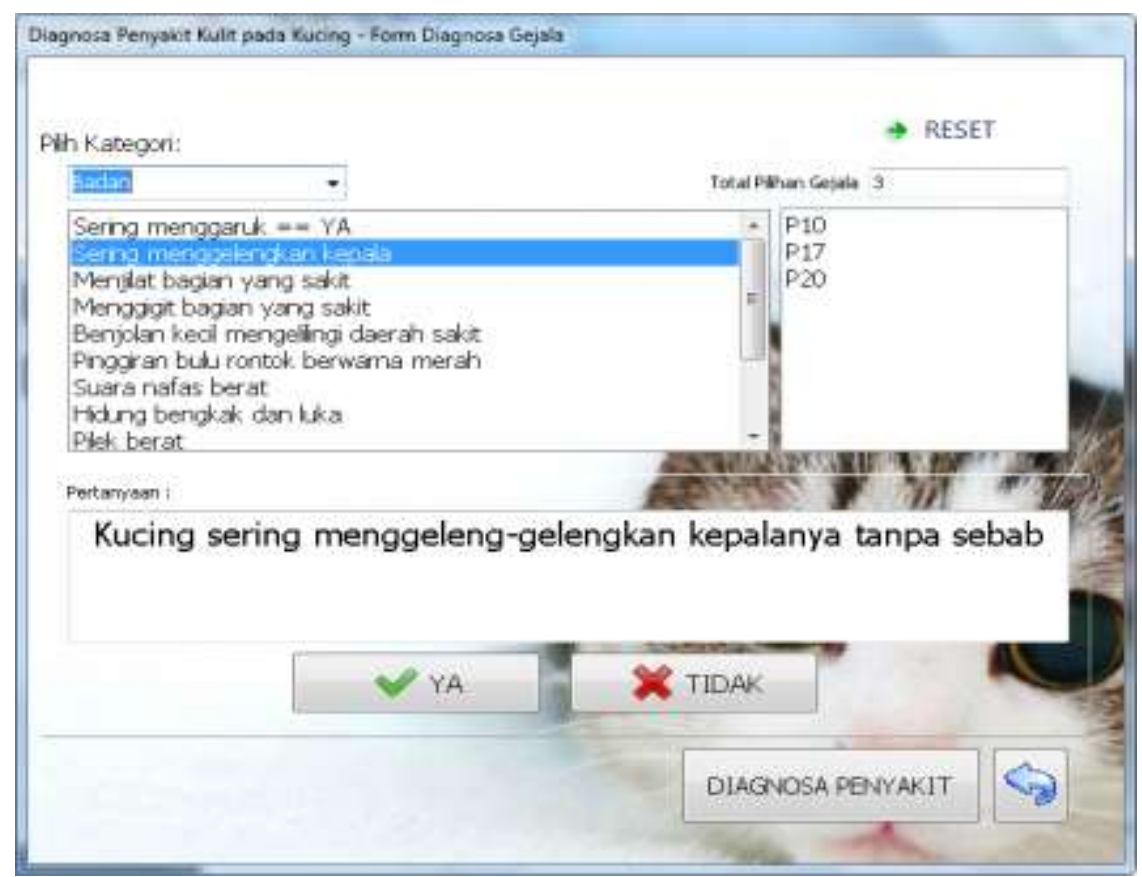

Gambar 5. Contoh Kasus Pemilihan Gejala Penyakit

Setelah user memilih gejala penyakit yang diderita oleh kucing, user dapat mengklik button "Diagnosa Penyakit" untuk mengetahui hasil diagnosa. Sistem akan menampilkan hasil kemungkinan penyakit dan besar nilai kemungkinan (belief) terhadap penyakit yang diderita seperti gambar 6 .

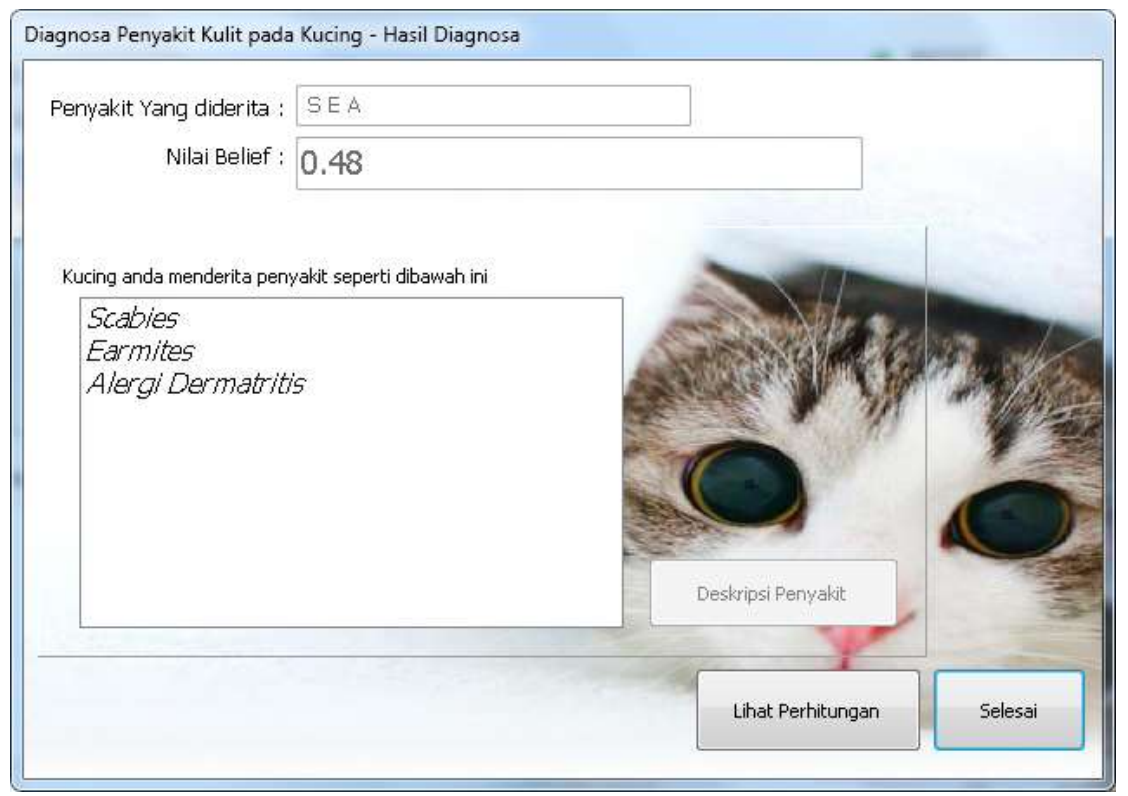

Gambar 6. Contoh Kasus Hasil Diagnosa Penyakit

Untuk mengetahui deskripsi penyakit dan saran pengobatannya, user dapat mengklik nama penyakit, lalu menekan button "Deskripsi Penyakit" seperti contoh pada gambar 7 . 


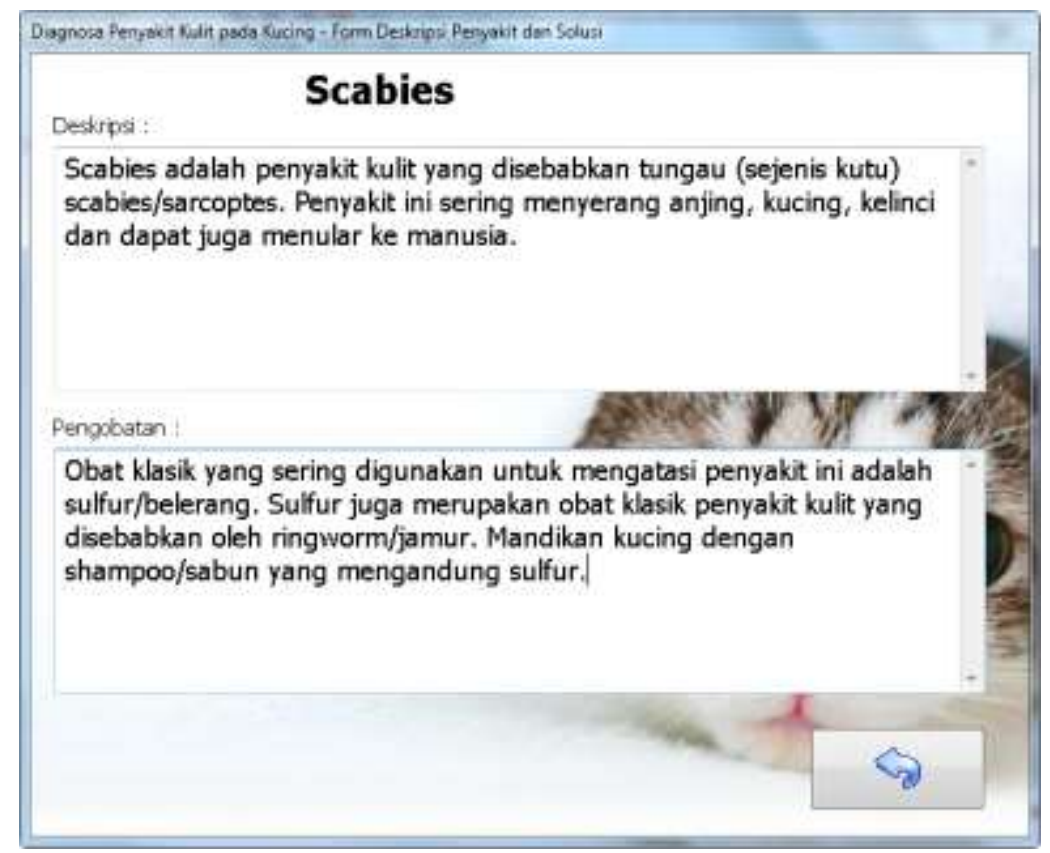

Gambar 7. Contoh Kasus Deskripsi dan Saran Pengobatan

Jika user ingin melihat rincian perhitungan yang sesuai dengan Metode Dempster Shafer, user dapat mengklik button "Lihat Perhitungan" dan sistem akan menampilkan form rincian hasil perhitungan seperti gambar 8.

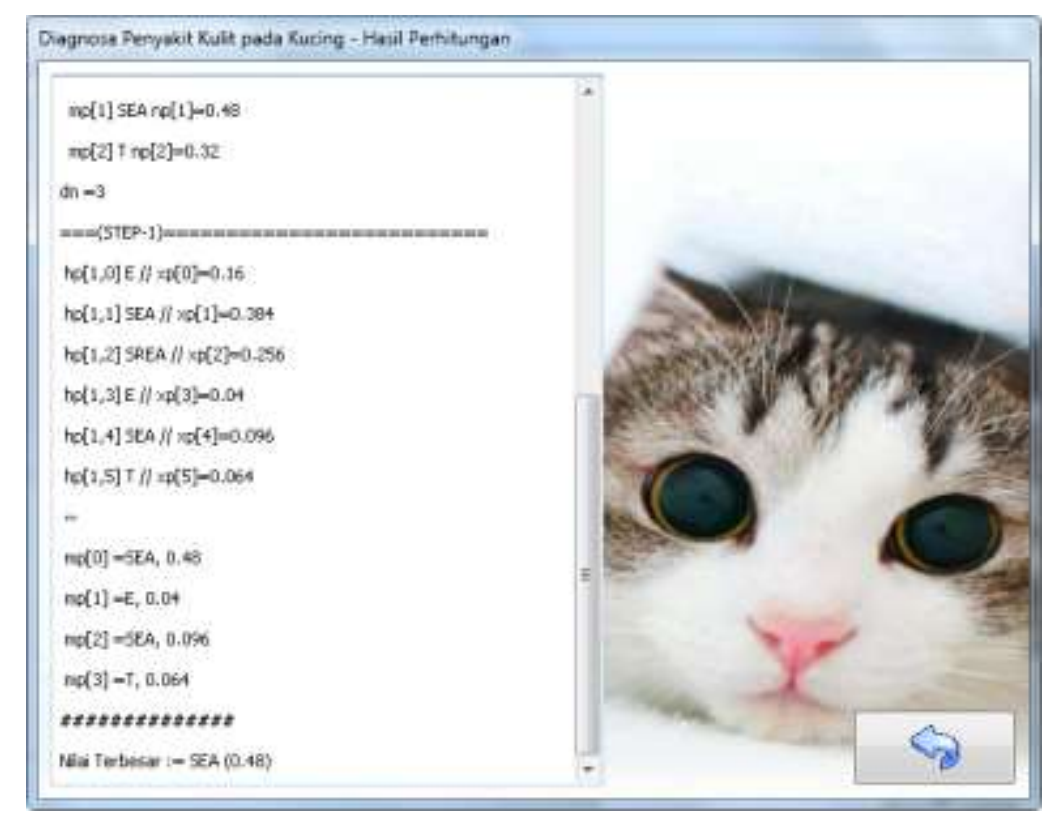

Gambar 8. Contoh Kasus Hasil Perhitungan Gejala Penyakit

Proses perhitungan secara manual mengenai diagnosa penyakit kulit pada kucing dalam kasus ini dapat dilihat pada rincian berikut:

a. Gejala 1 : Kerak Kering Basah 
Langkah pertama hitung nilai dari belief dan plausability dari gejala kerak kering basah yang merupakan diagnosa dari penyakit Scabies (A1), Ear Mites (A3), dan Alergi Dermatitis (A4), maka :

$\mathrm{m}_{1}\{\mathrm{~A} 1, \mathrm{~A} 3, \mathrm{~A} 4\}=0,6$

$\mathrm{m}_{1}\{\varnothing\} \quad=1-0,6=0,4$

b. Gejala 2 : Bagian Dalam Telinga Basah / Lembab

Kemudian apabila diketahui adanya fakta baru, yaitu adanya gejala bagian dalam telinga basah / lembab yang merupakan diagnosa dari penyakit Ear Mites (A3), maka nilai keyakinannya adalah :

$\mathrm{m}_{2}\{\mathrm{~A} 3\}=0,2$

$\mathrm{m}_{2}\{\varnothing\}=1-0,2=0,8$

Untuk memudahkan dalam perhitungan, maka dapat diilustrasikan nilai keyakinan terhadap dua gejala dalam tabel sebagai berikut :

Tabel 4. Perhitungan Nilai Keyakinan untuk Contoh Kasus

\begin{tabular}{llllll}
\hline & & $\mathrm{m}_{2}\{\mathrm{~A} 3\}$ & 0,2 & $\mathrm{~m}_{2}\{\varnothing\}$ & 0,8 \\
\hline $\mathrm{m}_{1}\{\mathrm{~A} 1, \mathrm{~A} 3, \mathrm{~A} 4\}$ & 0,6 & $\{\mathrm{~A} 3\}$ & 0,12 & $\{\mathrm{~A} 1, \mathrm{~A} 2, \mathrm{~A} 4, \mathrm{~A} 5\}$ & 0,48 \\
& & & & & \\
$\mathrm{~m}_{1}\{\varnothing\}$ & 0,4 & $\{\mathrm{~A} 3\}$ & 0,08 & $\{\emptyset\}$ & 0,32 \\
\hline
\end{tabular}

Selanjutnya menghitung tingkat keyakinan $\left(\mathrm{m}_{3}\right)$ combine dengan rumus:

$$
\begin{array}{ll}
\mathrm{m}_{3}\{\mathrm{~A} 3\} & =0,12+0,08 /(1-0)=0,20 \\
\mathrm{~m}_{3}\{\mathrm{~A} 1, \mathrm{~A} 3, \mathrm{~A} 4\} & =0,48 /(1-0)=0,48 \\
\mathrm{~m}_{3}\{\emptyset\} & =0,32 /(1-0)=0,32
\end{array}
$$

Nilai keyakinan paling kuat adalah terhadap penyakit $\{A 1, A 3, A 4\}$ yaitu sebesar 0,48 , yang didapat dari dua gejala yang ada yaitu kerak kering basah dan bagian dalam telinga basah / lembab.

c. Gejala 3 : Sering Menggaruk

Kemudian apabila diketahui adanya fakta baru, yaitu adanya gejala sering menggaruk yang merupakan diagnosa dari penyakit Scabies (A1), Ring Worm (A2), dan Ear Mites (A3), dan Alergi Dermatitis (A4) maka nilai keyakinannya adalah :

$\mathrm{m}_{4}\{\mathrm{~A} 1, \mathrm{~A} 2, \mathrm{~A} 3, \mathrm{~A} 4\}=0,8$

$\mathrm{m}_{4}\{\varnothing\} \quad=1-0,8=0,2$

Untuk memudahkan dalam perhitungan, maka dapat diilustrasikan nilai keyakinan terhadap tiga gejala dalam tabel 5 sebagai berikut :

Tabel 5. Perhitungan Nilai Keyakinan untuk Contoh Kasus

\begin{tabular}{lrlrlr}
\hline & & $\mathrm{m} 4\{\mathrm{~A} 1, \mathrm{~A} 2, \mathrm{~A} 3, \mathrm{~A} 4\}$ & 0.8 & $\mathrm{~m} 4\{\varnothing\}$ & 0.2 \\
\hline $\mathrm{m} 3\{\mathrm{~A} 3\}$ & 0.20 & $\{\mathrm{~A} 3\}$ & 0.160 & $\{\mathrm{~A} 3\}$ & 0.040 \\
$\mathrm{~m} 3\{\mathrm{~A} 1, \mathrm{~A} 3, \mathrm{~A} 4\}$ & 0.48 & $\{\mathrm{~A} 1, \mathrm{~A} 3, \mathrm{~A} 4\}$ & 0.384 & $\{\mathrm{~A} 1, \mathrm{~A} 3, \mathrm{~A} 4\}$ & 0.096 \\
$\mathrm{~m} 3\{\varnothing\}$ & 0.32 & $\{\mathrm{~A} 1, \mathrm{~A} 2, \mathrm{~A} 3, \mathrm{~A} 4\}$ & 0.256 & $\{\varnothing\}$ & 0.064 \\
\hline
\end{tabular}


Selanjutnya menghitung tingkat keyakinan $\left(\mathrm{m}_{5}\right)$ combine dengan rumus:

$$
\begin{array}{ll}
\mathrm{m}_{5}\{\mathrm{~A} 3\} & =0.160+0.040 /(1-0)=0.20 \\
\mathrm{~m}_{5}\{\mathrm{~A} 1, \mathrm{~A} 3, \mathrm{~A} 4\} & =0.384+0.096 /(1-0)=0.48 \\
\mathrm{~m}_{5}\{\mathrm{~A} 1, \mathrm{~A} 2, \mathrm{~A} 3, \mathrm{~A} 4\} & =0.256 /(1-0)=0.256 \\
\mathrm{~m}_{5}\{\varnothing\} & =0.064 /(1-0)=0.064
\end{array}
$$

Nilai keyakinan paling kuat adalah terhadap penyakit $\{\mathrm{A} 1, \mathrm{~A} 3, \mathrm{~A} 4\}$ yaitu sebesar 0,48 , yang didapat dari tiga gejala yang ada yaitu kerak kering basah, bagian dalam telinga basah / lembab dan sering menggaruk.

Dengan adanya kelima gejala tersebut maka diperoleh nilai keyakinan paling kuat adalah terhadap penyakit Scabies (A1), Ear Mites (A3), dan Alergi Dermatitis (A4), yaitu sebesar 0,48. Perbandingan proses diagnosa awal penyakit kulit pada kucing dengan menggunakan metode Dempster-Shaffer antara proses manual dengan program aplikasinya mencapai tingkat keberhasilan 100\%.

\section{SIMPULAN}

Simpulan yang dapat diperoleh dari penelitian ini adalah: mendapatkan hasil Nilai keyakinan paling kuat terhadap penyakit kulit kucing $\{A 1, A 3, A 4\}$ yaitu sebesar 0,48 , yang didapat dari tiga gejala yang ada yaitu kerak kering basah, bagian dalam telinga basah lembab dan sering menggaruk.

\section{DAFTAR PUSTAKA}

[1] A. Suwed, Muhammad. 2012. Panduan Lengkap Kucing. Jakarta: Penebar Swadaya.

[2] Alex. 2012. Panduan Lengkap Anjing \& Kucing. Yogyakarta : Pustaka Baru Press.

[3] Arhami, M. (2004). Konsep Dasar Sistem Pakar. Yogyakarta: Andi .

[4] Dahria, Muhammad. 2013. Sistem Pakar Metode Dempster Shafer Untuk Menentukan Jenis Gangguan Perkembangan Pada Anak. STMIK Triguna Dharma. Medan.

[5] Giarratano, J. and Riley G., 2005, Expert Systems ; Principles and Programming, PWS Publishing Company, Boston.

[6] Gita, Malinda. 2014. "Rancang Bangun Aplikasi Sistem Pakar Untuk Diagnosa Awal Penyakit Kulit Pada Kucing Menggunakan Metode Dempster Shafer". Skripsi Program Studi Ilmu Komputer, Universitas Lambung Mangkurat. Banjarbaru.

[7] Gustri, Elyza. dan Prijodiprojo, Widodo. 2008. Prototype Sistem Pakar Untuk Mendeksi Tingkat Resiko Penyakit Jantung Koroner Dengan Metode Dempster Shafer. FTI UUI. Yogyakarta.

[8] Kursini. (2008). Aplikasi Sistem Pakar. Yogyakarta: Andi.

[9] Pranoto, Ahmad Ngudi. 2012. Sistem Pakar Diagnosa Penyakit Kucing. Tulang Bawang.

[10] Prima, Rony. 2009. Sistem Pakar Untuk Mendiagnosa Penyakit dan Pengobatan Pada Kucing Berbasis Web. UPI-YPTK. Padang.

[11] Soeharsono. 2002. Zoonosis Penyakit Menular dari Hewan ke Manusia Volume 1. Kanisius. Yogyakarta. 
[12] Soeharsono. 2007. Penyakit Zoonotik pada Anjing dan Kucing. Kanisius. Yogyakarta.

[13] Sulistyohati, A., dan Hidayat, T., 2008. Aplikasi Sistem Pakar Diagnosa Penyakit Ginjal dengan metode Dempster-Shafer. Seminar Nasional Aplikasi Teknologi Informasi. SNATI UII. Yogyakarta. 